UDC 378.14

Bacurovska Ilona

ORCID iD: 0000-0002-2269-7318

Ph.D.(Pedagogical Sciences), Associate Professor of the Department of Electrical Engineering and Electromechanics at Mykolayiv National Agrarian University, Mykolayiv,

bacurovska82@hotmail.com

\title{
WAYS TO INTEGRATE EUROPEAN MASSIVE OPEN ONLINE COURSES IN UKRAINE'S UNIVERSITY EDUCATION
}

\begin{abstract}
Educational online courses are gaining increasing popularity. Education is one of the few areas where age and preservation of traditions are benefits. Unlike the modern offline education, this study is caused by personal motivation and desire to gain the necessary knowledge. In world practice, a concept of massive open online courses appeared long time ago. The paper provides an analytical review of ways of implementing European massive open online courses in university education of Ukraine and their capabilities. Higher education needs urgent restructuring. Massive open online courses can help students combine their acquisition effectiveness and ease of scalability.

Keywords: educational sphere; massive open online courses; platforms; university education.

Key Terms: information; information-and-communication technology; technology.

(C) Bacurovska Ilona, 2017

1 Introduction

Educational online courses are gaining increasing popularity. In Bologna in 1088 was opened the first university and the form of higher education has not changed much. Education is one of the few areas where age and preservation of traditions are benefits. That's why so many people are enthusiastic about the idea, that «massive open online courses» will revolutionize the educational sphere. During the last years many institutions, including Harvard, Stanford and Massachusetts Institute of Technology (MIT), began to hold free online courses to anyone who wants to hear them. Hundreds of thousands of students can register for each course. Nearly 300,000 students signed up to first six courses by the University of Edinburgh during the first week after the opening of registration. Coursera, a leading platform of massive open online courses, last month announced a set of 90 new courses available in Chinese, Spanish and other languages.
\end{abstract}


Higher education needs urgent restructuring. In the USA, the cost of an hour of teaching reaches \$ 100 per student. In developing countries, the educational sphere is not able to grow such a pace to satisfy growing demand; at the current rate of growth in 2020 India will have more adults without higher education than now. The costs of higher education are often disposable: most of the students cannot afford to get another degree, if the first does not correspond the profession. Considering this, young people can choose massive open online courses for further education. These courses can satisfy the demand of students especially from countries that are in a state of development. Massive open online courses can help students combine their acquisition effectiveness and ease of scalability.

\section{The aim of the article}

Goal of this article is an analytical review of ways of implementing European massive open online courses in university education of Ukraine and their capabilities.

\section{The main body of the article}

Unlike the modern offline education, this study is caused by personal motivation and desire to gain the necessary knowledge. In world practice, a concept of massive open online courses appeared long time ago. In autumn 2011, Stanford University offered all comers three courses via the Internet free of charge. More than five thousand public courses appeared on the initiative of MIT, and therefore, there is a question how to use them. Online courses provide an open content, where «open» is used in the sense of freedom from intellectual property and allows re-use of content. Stanford University has been testing the technology of education in massive open online courses over the years. Created courses, interviews with teachers, leading classes and course works showed, that interest to the possibilities of this method has grown significantly. In thematic discussions forums scholars and professors at Stanford were very interested in using mixed learning, basic element of which are massive open online courses. They noted that such training might be able to provide a wider audience than the traditional classroom sessions. Massive open online courses give teachers and students the opportunity to develop skills, knowledge and thinking needed to participate in complicated and shifting real situations. Open learning is the most transparent and convenient open practice (Anderson Terry, 2015; OER, 2011).

The difference between the openness of practice and the openness of contents matters is great. Creating the contents takes time, effort and resources and triggers numerous discussions as regards the intellectual property rights. The openness of practice does not require gross additional investments insomuch as it basically concerns the activities which have been already pre-planned by the educator. An open learning process is an important aspect of openness in the framework of the entire educational sphere. This is particularly useful for the adults' professional environment when the courses are attended by attendees with various skills and needs. A training program can be tailored to the attendees' needs during the learning process. Attendees themselves become open to various nonconventional educational models. The educator plays an important role in ensuring interaction, exchange of information and resources, participation in discussions; he also fosters the growth of knowledge in the attendees. Learning calls for active participation on the part of all its participants. With large-scale courses, it often results in student subnetworks being created to deal with certain questions. 
Open education is an element of innovative theory. The today's world has been actively researching the problems and methods of introducing innovative theory into educational structures. Based on the experience of introducing information educational innovations abroad, we have singled out the following basic requirements and tendencies on which educational innovations should be focused:

1) Accessibility of education. As for this paragraph, it is important to take into consideration both accessibility of education for all population strata, irrespective of the geographical location, and relevant opportunities for obtaining education throughout entire person's life, also irrespective of the geographical location and time.

2) Individualization in education. Benjamin Bloom's research (Kukharenko V. N, 2013) demonstrates differences between the results of lecture-based, programmed and individualized learning. 98\% of students and learners in an individualized learning class showed the results which were better than those of the other classes.

3) Educational institutions should develop and offer their new innovative brand to the «educational market». By selling such brand they will be able to attract and retain the talented people.

4) One way or another, educational innovations should be connected with the information and communication technologies. Thus, there may be distinguished the technologies which introduce innovations directly in the learning process, such as distance learning, massive online courses, electronic libraries; and the technologies which create a relevant infrastructure for the introduction of information innovations, such as cloud computing.

In the framework of this article we would like to focus on a technology which radically changes the concept of an educational institution and which takes the questions about the effectiveness of traditional educational institutions to a new level. These are the technologies of massive open online courses which appeared in response to the needs of the contemporary society in the massive online access mode to the qualitative educational resources, irrespective of the place of residence or status of course attendees. In Ukraine, the use of open massive online courses may be regarded as a contemporary means of obtaining electronic information. However, massive open online courses have been used broadly enough in the foreign pedagogical practice. Again, it is worthwhile noting that, as for all innovative technologies related with self-education, a high level of motivation and self-control of a course attendee is an important aspect of the online courses effectiveness, because it is the attendees themselves that determine the strategy of their education. The technology of massive open online course has not emerged out of nowhere, it is rather a logical development of the open educational courses and online education.

Platforms of the massive open online courses comprise lots of pedagogical tools: video lectures, online reading and problem sets which are placed throughout the entire online course curriculum, interactive forums, which help students create communities, evaluate each other's work, etc. Such kind of interactivity serves as the central nexus of massive open online courses, all due to greater interaction of the students with one another (Lewin Tamar,2013; Gram T, 2009).

Assessment of a student work by fellow course attendees has proven its potential from the pedagogical point of view. Keith Devlin, Stanford Professor, who teaches at the massive open online courses on mathematical thinking which are popular among the 
students, notes: «It's just like riding a bicycle: there is only one way to learn - you sit on it, fall, sit, fall but then one day you will develop a certain skill of a relevant reaction. In mathematics, such skill will only develop if you are a student and if you've been checking student works». The system when student evaluate their own works is an integral portion of the platform of massive open online courses. It ensures effective feedback with a colossal aggregation of student works. In such circumstances, a student gains experience in checking the works of the others which helps them evaluate their own knowledge.

As such, the term «massive open online course» was introduced by George Siemens in 2008. The word «massive» refers, in the first place, to the number of students. That same year Siemens conducted his first online course dedicated to the issues of a new learning theory, that of connectivism (Kukharenko V. N., 2012), according to which learning is a process of creating a network. The nodes of such network are external entities (people, organizations, libraries, websites, books, magazines, database or any other source of information). The act of learning consists in creating an external network of nodes. The connectivism principles contained in massive open online courses are: diversity of approaches; visualizing learning as a process of developing a network and making decisions; learning and cognition occur continuously; it is always a process, rather than a status; a key skill today is an ability to identify ties and understand meanings between the spheres of knowledge, concepts and ideas; knowledge may exist in a network beyond an individual; technologies help us learn.

Massive open online courses build on active engagement of several hundred to several thousand attendee students who self-organize their participation according to learning goals, prior knowledge and skills, and common interests (McAuley Alexander, Stewart Bonnie, Siemens George and Cormier Dave, 2010). Such courses are a model of semantic network, wherein an LMS system is confined to one network node and is mainly used for management tasks.

Massive open online courses have a global, rather than a regional character and extend beyond the limits of a university. Four factors limiting the participation of students in the conditions of such courses may be delineated (Masters Ken, 2011):

1. A great volume of information can mislead a course attendee, that is why an educator needs to provide the structuring;

2. Social aspects may create tension within a group where people of different cultures, languages of communication and levels of training participate in the learning process.

3. Technological aspects may influence participation of students in some regions;

4. Additional barriers may arise due to attendees living in different time zones.

Massive open online courses mitigate barriers in learning and augment student selfsufficiency. Students acquire professional skills for participation in global interactions. Courses serve as a method for augmenting knowledge in a segmented, global, digital environment and are significantly important for the future society. Attendees to a massive open online course set learning goals to themselves, and such goals may vary during the period of learning, they read only such materials which may be accessible to them and which they like. They cannot simply read everything because of the enormous number of sources. They should express their views and defend their positions in the operation of 
thematic forums of a massive course. It is necessary to be open to achieve the best possible effect from learning.

It should be noted that to achieve a goal set an attendee should observe the following elements while studying at a massive open online course (Kukharenko V. N, 2013):

-Be goal-oriented and assist students in outlining routes in huge volumes of information;

-Be open to a great number of interpretations;

-Be accessible to participants having different levels of experience in a given topic.

An educator builds the environment and serves as a "crystallization center» for the learning process. A real result depends on the activity of a student and may be achieved after the completion of the course as well.

Both positive and negative features may be identified in a massive open online course (Kukharenko V. N, 2013). The positive ones may include the following:

- An open course attracts participants from all over the world having different cultures, traditions and levels of knowledge at a given time period, which entails the emergence of a very dense cloud of knowledge, whose density may exceed that of a Google or Wikipedia search result.

-An open course facilitates emergence of strong ties between the participants, depending on their social preferences.

The negative features may include the following:

- The open course knowledge is very fragmented. It is quite difficult to collect them, especially after completion of the course.

-A problem of references arises as it is very difficult to reference a cloud of knowledge.

It should be noted that massive open online courses depend upon the skills, intrinsic motivation, goals set, overall cultural level and student technical literacy. A massive open online course builds on the four basic kinds of activities (Kukharenko V. N, 2013):

1. Collaboration. The course provides references to various information materials which are necessary to read and discuss. It is difficult to read all of the materials, there are lots of them. A student chooses the materials they like and are interested in. In the course of collaboration with the others he/she may receive a generalized idea of a respective section of the course. The student regularly receives an electronic bulletin in which certain current issues are covered (In his courses G. Siemens sends such bulletins every day).

2. Remix. After the reading and participation in the webinars the next step for a student is to track and record the events which are close to his/her understanding of the course's material. It depends upon a student to determine how to do that. He/she can save the document on their computer or on the Internet and share their content with the others.

3. Reprofiling. The main task of the massive open online course is to assist a participant in creating their own content rather than reiterate the others' words. And this is the most complex portion of the learning process. The learning does not start from scratch, that is why the term "reprofiling" is used in the course instead of "creating». A course attendee works with materials rather than starts from zero. These materials may be used to express student's own ideas and understanding of the material. An open course teaches how to read, understand and work with the other people's content and how to create one's 
own new understanding. A course, as a rule, offers the tools to use in order to create one's own content.

4. Messaging. The task of a massive open online course educator lies in ensuring the common work with other people in a given learning process. A student is not obliged to share the information. He can work completely independently without showing anything to anybody. The shared use of the information is the choice of a student. It is more difficult to participate in the common work. It is easier to spot mistakes of another. On the other hand, people value good job, too. It is the exchange of messages that will create the content of the course. Each week starts from briefly posting a topic and making references to certain sources. Each day all course attendees receive e-mails about the activity or about important resources with the help of a mailing list. As a rule, two webinars are held during a week. One webinar consists of the speech of a guest lecturer dedicated to a certain topic; the other is the discussion of the week's topic.

The work in a course may last five to ten hours per week and consist of the participation in discussions, webinars and writing blogs. If a student cannot dedicate the necessary amount of time, he/she can choose the level of participation which best suits his/her possibilities and requirements. Recommendations for a student activity in a massive open online course may be defined as follows:

1. It is worthwhile setting several goals: What is necessary to achieve from the course? How much time is it necessary to dedicate for studying the course? Share the goals set at the discussion forum «Acquaintance».

2. It is desirable to install in one's browser a Google translator for reading documents in different languages.

3. It is worthwhile creating a memory card of the course by adding new concepts and ideas on a weekly basis. The memory card may be useful in communicating with the course participants.

4. To comprehend the materials dealt with an attendee can use a blog, and, where necessary, a blog may even be created.

5. It is necessary to selectively get familiarized with the proposed course materials.

6. It is necessary to participate in the discussions at the course forums.

One of the important aspects of the massive open online courses is the availability of a personal learning environment - a term which emerged several years ago in the western literature and which is related with the practical application of the ideas of e-learning 2.0. Creating the personal learning environment is based on cloud computing, i.e., performance of the programs located on the servers (Rosenberg M., 2007), which provides certain advantages:

-The software is monitored and controlled;

-The management of the versions of software is simplified;

- The dangers of virus spread are reduced to a minimum;

- The basic data and the files received can be stored and managed on a centralized basis on the firewall servers;

- One can work on simple computer configurations.

The organization of the learning process in massive open online courses envisages the following: the theoretical and practical portions, control in process, feedback and final 
assessment. The theoretical material in massive open courses is, as a rule, provided in the form of lectures which are subdivided into portions lasting 2-10 or 10-20 minutes, each of which ends with a test, a quiz or test questions to verify the understanding of the material. Lectures are most often posted in the recorded form (Prometheus, 2014). The theoretical material and formulas are usually provided with the help of a digitized pad. The teaching information is transmitted vocally with the explanatory graphs, schemes and drawings created simultaneously. Additional theoretical material for the lectures is recommended in the references to Internet-sources.

Massive open online courses may include practicums. They are represented in the form of various assignments and projects which are carried out in online virtual laboratories. The control in process is carried out by automated checking of the results of execution of different kinds of assignments since an educator cannot check such an enormous amount of assignments in principle. Besides the multiple-choice assignments and questions requiring short self-generated answers, there are also offered open assignments with automated checking. In the last kind of assignments, the accuracy of models may be checked, whether they are the financial models from a business course or sufficiently difficult assignments from a programming course. The advantage of such control lies in obtaining rapid results, adjusting the quality of digestion of materials at each stage. (Karan Khemka, 2013).

Feedback is realized with the help of forums and online video meetings in real-time mode. A forum is viewed as a place where the participants can ask questions and help each other; express their impressions from taking a course; receive support and encouragement; find and post additional information that is relevant to the course; contact other students in order to form training groups, organize real meetings for communication and joint solution of the tasks set. The final assessment for the purpose of accumulation of credits required for counting university courses is carried out in the presence of attendees at specially organized locations. The final project is considered by the educator personally if a certificate is required to be issued.

Thus, massive open online courses are independent educational environments. Along with that, they facilitate the introduction of the state-of-the-art pedagogical technologies in the learning process. Thousands of those wishing to have been able to participate in the learning process under the motto of the «open courses». Massive open online courses have appeared in many countries of the world.

Since 2011 in Germany there have been held the massive open online courses OPCO11 (http://blog.studiumdigitale.uni-frankfurt.de/opco11/) - «Learning tendencies», OPCO12 (http://opco12.de/), MMC13 (http://howtomooc.org/uber-mmc13/) (development and implementations of MOOC), COER13 (http://www.coer13.de/news.html) - «Open educational resources», «Ichkurs» (http://ichkurs.de/) - «Development of leadership and communication». Platform OpenCourseWorld (http://opencourseworld.de/) has been working with several German Universites. The German project Iversity (http://www.iversity.org/) was founded in 2011 by Jonas Lipman and Hannes Klopper and has been striving to become a leading platform in Europe for the holding of massive open online courses. 10 courses with the total value of $€ 250,000$ are planned to be developed by October 2013(Siemens George, 2004). 
The Open University (Great Britain) has been forming a new platform for massive open online courses, that of Futurelearn (http://futurelearn.com/) which works in cooperation with more than 20 British Universities. Since 2007 in Ireland a provider Alison (http://alison.com/) has organized the online courses in the areas of management, accounting, customer care, human resources, medical investigations and basic skills of doing business. More than two million students have registered for these courses and more than 50000 certificates have been issued since 2011 (Ifenthaler, D. \& Gosper, M., 2014).

In April 2013 Inge Ignatia de Waard in Belgium published a book dedicated to mobile education. The University of Amsterdam in the Netherlands launched its first massive open online course dedicated to ties in science. Also in April 2013 a multi-faceted European platform OpenupEd.eu (http://www.openuped.eu/) was set up. This platform united partners from 11 countries of the world: France, Italy, Lithuania, Netherlands, Portugal, Slovakia, Spain, Great Britain, Russia, Turkey and Israel. Around 40 courses, such as mathematics, economy, e-commerce, climate change, cultural heritage, corporate social responsibility and modern Middle East will be accessible on a free of charge basis. In France an online business school Enaco (http://www.enaco.fr/) kicked off the first project of massive open online courses in the area of cross-cultural management in Europe. At the same time, it has been setting up an Internet training platform Telecom Bretagne (http://www.mines-telecom.fr/en_accueil.html). Spain has created a special Spanish-speaking platform створила спеціальну іспаномовну платформу Mooc.es (http://www.mooc.es/), which is a search system of massive open online courses all over the world. In addition to providing a description of the courses in the Spanish language, the main advantage of this platform consists in that it enables sorting the records of the databases depending on the language.

The Platform Miriada X (https://www.miriadax.net/) has been working with 1241 partner Universities from 23 countries in Latin America and represents 15300000 students and scientists. A joint development of the Universities of Portugal and Brasil - MOOC EAD (http://moocead.blogspot.de/) is the first massive open online course in Portuguese. The Open University of Portugal (http://www.uab.pt/) proposes a new project of massive open online courses (http://imooc.uab.pt/) in collaboration with OpenupEd. Each course of this project starts from the «training» module, which may last one or two weeks. It is used by the participants to get their bearings in a virtual environment, to get acquainted with the tools and services, achieving skills in online communication and cooperation.

The Open Universities Australia (OUA) launched a new free-of-charge online educational platform which is called Open2Study (https://www.open2study.com/) in March 2012. This is a result of cooperation between different universities, including the Macquarie University, Univeristy RMIT and the Central Technological Institute. OpenLearning.com (https://www.openlearning.com/) is a project by the University of New South Wales in Sydney, which started in November 2012. By now more than 13 courses have been available, including the skills of programming, marketing service, minor repair of the engine and the gaming world. The University of Western Australia (https://www.class2go.uwa.edu.au/) offers four open online courses, which are accessible via mobile devices. The courses are unique in that they use the online platform Class2Go, (https://class2go.stanford.edu/), which has been in the stage of merger with the platform EDX. Sunstone Business School in India (http://opencourses.sunstone.in/) offers two- 
week open online courses in the format of massive ones. The project EducateMe360 (http://educateme360.com/) has been at the stage of development with its task being that of improving the quality of education at all levels.

Latin America established a foundation in order to facilitate virtual education within the country - CSEV (http://www.csev.org/en_GB/home). This foundation offers massive open online courses through the Spanish platform named UNX (http://www.redunx.org/web/guest/home).

Despite a great number of the platforms on the global scale which have been developed for the massive open online courses, one of the largest providers of the online courses in the world is Coursera, with its main rivals being Udacity Company and a noncommercial project edX. 62 universities had become the partners of Coursera project by the end of February 2013. All of them expressed their readiness to provide the platform with its online courses with any person being able to watch them, irrespective of whether or not they are a student of any of the higher educational establishment. As of yet, Edx Company has announced joint programmes with six universities, however, by 2014 their number will have grown at least to twelve. At the same time, Udacity has been operating independently of the universities; in the opinion of Sebastian Thrun, its founder, the professors have no idea of how to present the material in the online system; that is why all lectures are developed by the company itself.

Massive open online course enable universities to save the working hours of the educators. If a classroom-based lecture is calculated for a limited number of students, a video lecture can be viewed by a great number of students. Such kind of lessons will help suspend the inflow of the students wishing to obtain the higher education in the American higher educational establishments every year. The Ministry of Education of Canada has estimated that if the current-day rate of growth of the planet's population stays the same, the humanity shall weekly build three universities for 30 thousand students so as to accommodate by 2025 all those wishing to study. It is also worthwhile noting that the digital programs have their positive impact on the image of the higher educational establishments, and the market of electronic education will grow by $23 \%$ by 2017 and become the most perspective segment of the educational industry. And, finally, if a correct business model is being utilized the online courses, even if they are free-of-charge, may bring significant profit to the universities: the basic product is provided to everybody free of charge, whilst the additional options (for example, an advanced subspecialized course or a course given by the major specialist in the field) and the certificates are to be paid for by the users (Cormier Dave, Siemens George, 2010; Results of the Course «History of Ukraine: from the Second World War to Modern Times»).

They have kicked off the massive open online courses in Ukraine too. A special platform - «Prometheus» - has been developed to this end. An array of massive open online courses has been developed by the advanced tutors of the universities of Ukraine and they started to register attendees for the same. The first four massive online courses of the project were provided by the tutors of the Taras Shevchenko KNU, PKI and KyivMohyla Academy. The goal of this project lies not only in establishing certain courses, but in creating interrelated cycles of the courses dedicated to the most topical issues for the country, such as business, innovative technologies, foreign languages, law, history, etc. 
Each course in «Prometheus» project consists of video lectures given by the leading tutors of the best Ukrainian higher educational institutions, of interactive tasks enabling to strengthen the knowledge received, as well as of a forum at which the students will have a possibility to ask a question of a tutor and to communicate with each other. Everything what will be needed to participate in such a course is just a computer and availability of the access to Internet. The first courses of the project were «The History of Ukraine: from the Second World War to the Present Days» contributed by Ivan Patryliak, a tutor of the Taras Shevchenko Kyiv National University, «Financial Management» contributed by Olexiy Herashenko, a tutor of the Kyiv-Mohyla Business School, «Basics for Programming by Using Python Language» contributed by Nikita Pavliuchenko, a tutor of the Kyiv Politechnical University and «Development and Analysis of Algorithms», also by a tutor of Kyiv Politechnical University - Olexiy Molchanovsky. A successful completion of this massive open online course will enable to be granted an electronic certificate which will confirm the knowledge obtained.

The tasks of the project may include the following:

-To provide an attendee with a free-of-charge online access to the best universitylevel educational courses irrespective of the place of residence, financial status and state of health,

- To create not just single courses, but interrelated sequence of the courses (programming, business, foreign languages, history,for massive open online courses like edX and Coursera,

- To organize appropriate issuance of certificates to the attendees who have successfully completed a course,

- To carry out an experimental launch of mixed courses whose format envisages the utilization of the massive open online courses in the learning process in the form of lectures and control in process with the tutors holding workshops at the campus and with the final control of the student knowledge being in the form of examinations.

A student will register at the site and select a course required, which will be divided into blocks depending upon the time spent for the studying of material per week. A student will then once again view the video lectures, discuss the questions at the forum, pass interactive tests and be granted a certificate on completion of the education. Besides, the adaptive dynamics in the conditions of the platform enables to equally conveniently make use of the materials of the resource at a notebook, tablet or a smart phone. The main massive open online courses of this platform are as follows: «The History of Ukraine: from the Second World War to the Present Days»; «Financial Management»; «Basics of Programming»; «Development and Analysis of Alogrithms»; «Introduction into business analytics»; «Psychology of stress and ways to handle it»; «Theory of Limitations and Processes of Thinking as a Powerful Approach to business management»; «Communicative tools for building a reputation»; «Basics of information safety»; «Consumer rights protection: theory and practice».

Let us look at the results of completing the course «History of Ukraine: from the Second World War to the present days» contributed by Ivan Patryliak, the tutor of Taras Shevchenko KNU, in the conditions of Prometheus platform, e-mail address http://edx.prometheus.org.ua/courses/KNU/101/2014_T2/info. The course is intended to run 5 weeks. The first week is dedicated to the topic «Ukrainian lands before and during 
the First Years of the Second World War (1939-1941)»; the second one - to the topic «Fighting between the Wehrmacht and the Red Army in the Territory of Ukraine during 1941-1942», the third one - to the topic «Fighting between the Wehrmacht and the Red Army in the Territory of Ukraine during 1943-1944», the fourth one - to the topic «Ukraine in the Nazi project of "New Europe (1941-1944)», the second one - to the topic «Restoration of the Soviet regime and state-planned economy in Ukraine (1943-1953)».

On 9 January 201510428 attendees were registered at the course, 792 of them were granted certificates, which gave us evidences of a full completion of the course. This is almost $8 \%$ of the total number of the attendees. Considering that the registration is open permanently, the tasks did not contain any deadlines whilst the number of the attendees was growing increasingly, it would have been more accurate to use the number of the registered persons by the end of the first week of the course rather than the number as of 9 January 2015. If so, the percentage of those who successfully completed the course would have been considerably higher (The MOOC Juggernaut, 2016).

The results of completing weekly tests are displayed at Picture 1.

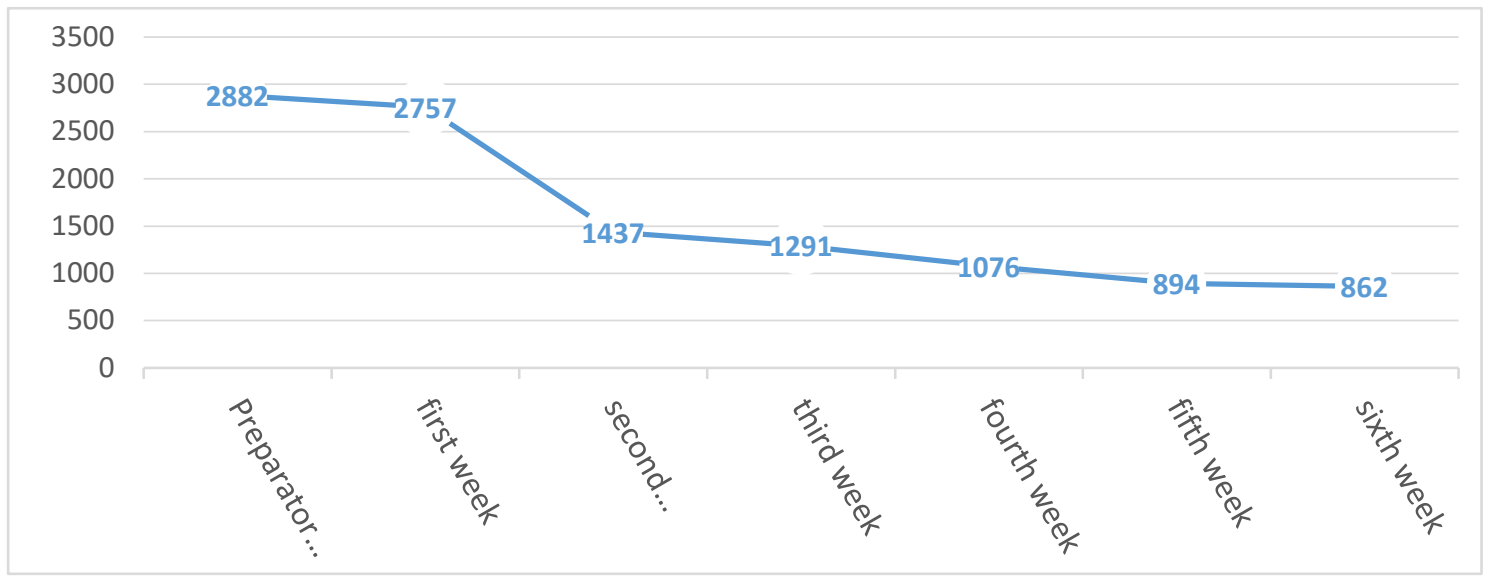

Picture 1. Weekly tests completion results

Based on the test results we can affirm that almost three thousand attendees passed the entrance testing, the first testing - almost two thousand, the second one - almost one thousand and a half, the third and the fourth ones - almost nine hundred attendees.

Let us present in the form of a diagram (Pict.2) the distribution by age groups of all the attendees registered for the massive open online course «History of Ukraine: the Second World War to the present days» in the conditions of Prometheus platform (Results of the Course «History of Ukraine: from the Second World War to Modern Times»). It is worthwhile noting that the massive open online course does not envisage definite deadlines. Due to the fact that the registration is open, there is a great likelihood that the rate of the registered attendees continued to grow after the beginning of the learning process. 


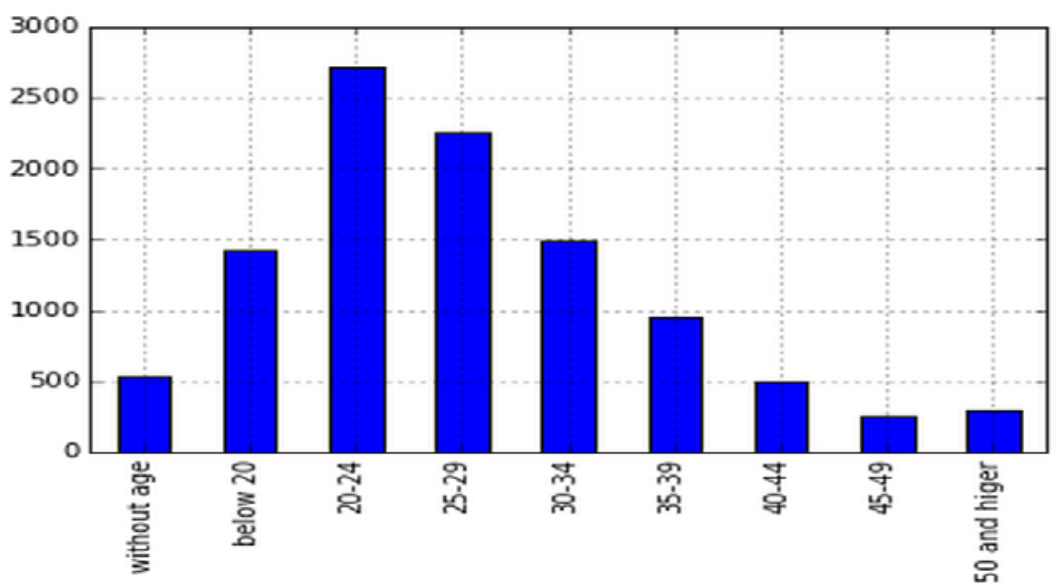

Picture 2. Distribution by age groups of the attendees who registered for the massive open online course «History of Ukraine: from the Second World War to the present days» in the conditions of Prometheus platform

It is clear from the diagram that almost 1.5 thousand attendees aged under 20 studied the course materials. The biggest rate was recorded for the attendees aged 20 to 24 years, almost three thousand people. There were almost 2.5 thousand attendees aged 25 to 29 years who studied the course. The number of the course attendees aged 30 to 34 was equal to 1.5 thousand while there were almost one thousand course attendees aged 35 to 39 . The course was taken by almost 500 people aged 40 to 44 . The rate of completing the course by the attendees aged from forty years did not exceed 500 . The number of the attendees who did not specify their age was more than 500 .

The quantitative indicators of the attendees who completed the massive open online course «History of Ukraine: The Second World War to the present days» granted by Ivan Patrylak, a tutor of Taras Shevchenko KNU, in the conditions of Prometheus platform, may be represented as a percentage at Picture 3 (Results of the Course «History of Ukraine: from the Second World War to Modern Times»).

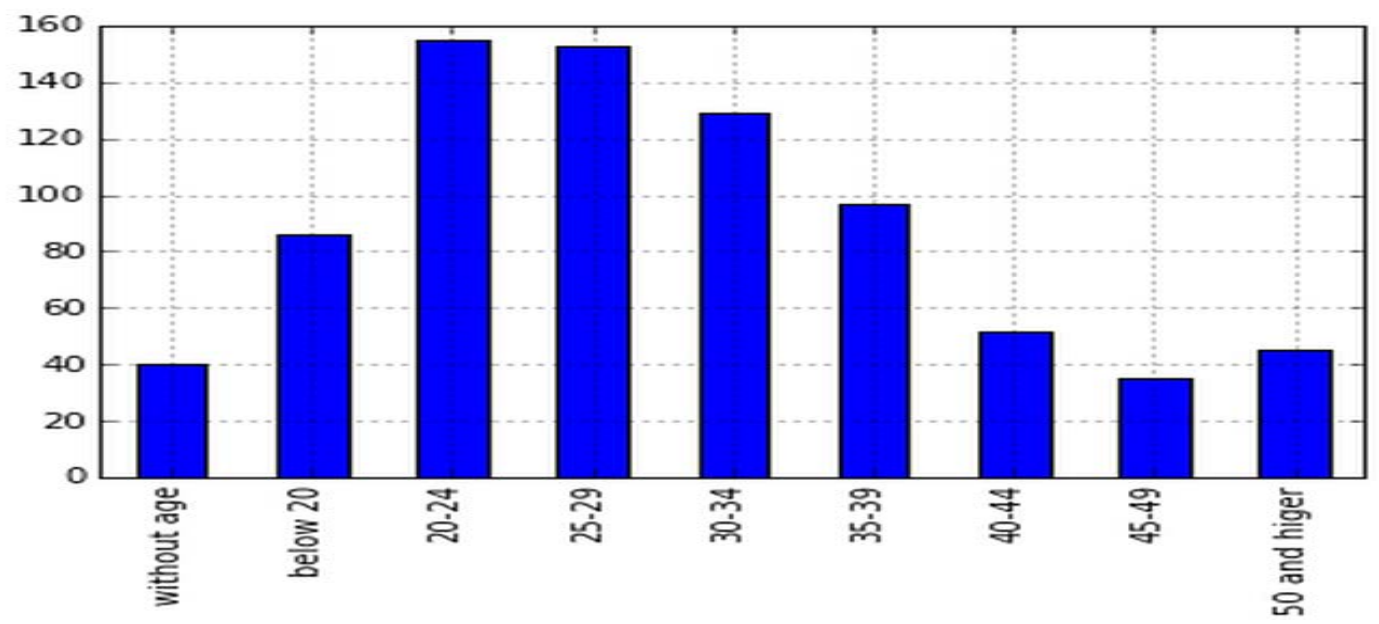

Picture3. The quantitative indicators of the attendees who completed the massive open online course «History of Ukraine: the Second World War to the present days» granted by Ivan Patrylak, a tutor of Taras Shevchenko KNU, in the conditions of Prometheus platform

The research enables us to affirm that out of 791 participants of the massive open online course it was the attendees aged 20 to 29 who became the most active participants. They were almost 320 in number. The numbers of the attendees aged under twenty and 
those aged 35 to 39 did not exceed 200. The number of the attendees aged 30 to 34 who were granted the certificates on completion of training, was more than 120 . The attendees of other age categories were not more than 200 in number.

The demography of the students of the course «History of Ukraine: from the Second World War to the present days» consists of 79 countries of the world and of 180 cities, towns and settlements of Ukraine. Among the leaders are Kyiv, Lviv, Kharkiv, Dnipropetrovsk, Odesa, Ivano-Frankivsk, Ternopil, Zaporizhia, Donetsk and Vinnytsia (Results of the Course «History of Ukraine: from the Second World War to Modern Times»).

\section{Conclusions}

Thus, the emergence of massive open online courses fosters the implementation of education in the modern world. The development prospects of these courses is related with further advancement of systems of the open education that is proposed by such projects as Coursera, EDX, Udacity and other leading platforms. Massive open online courses are such courses, which are focused on the participation in large-scale online education systems through an open access in the Internet network. In addition to traditional materials, such as video and printed materials, such courses provide online opportunities to the users, thus enabling to create a community of students, educators, etc. Massive open online courses are the last stage of development in the distance education; these courses most frequently use open educational resources.

\section{List of References:}

1. Anderson Terry. Quality in Open Educational Resources (OERs) [E-resource]. Access mode: http://goo.gl/T478t

2. Cormier Dave, Siemens George. Through the Open Door: Open Courses as Research, Learning, and Engagement EDUCAUSE Review, vol. 45, no. 4 (July/August 2010): 30-39 [E-resource]. http://www.educause.edu/EDUCAUSE+Review/EDUCAUSEReviewMagazineVolume45 /ThroughtheOpenDoorOpenCoursesa/209320

3. Gram T. 10 Strategies for Integrating Learning and Work - [E-resource]. - Access mode: http://gramconsulting.com/2009/06/10-strategies-for-integrating-learning-andwork-part-1/

4. Karan Khemka. Moocs are no panacea for universities- [E-resource]. - Access mode: http://zgroup.com.ua/article.php?articleid=5343

5. Kukharenko V.N. Learning Process in a Massive Open Online Course Work - [Eresource]. - Access mode: http://www.kpi.kharkov.ua/archive/Tipuss/2012_1/Kuhar.pdf

6. Kukharenko V.N. Massive Open Online Courses in Ukraine. Ukraine. Proceedings of the 2013 IEEE 7th International Conference on Intelligent Data Acquisition and Advanced Computing Systems (IDAACS) Volume 2. 2013 - p. 760-763

7. Lewin Tamar. M.I.T. Expands Its Free Online Courses. The New York Times [Eresource]. - Access mode: http://www.nytimes.com/2011/12/19/education/mit-expandsfree-online-courses-offeringcertificates.html

8. Masters Ken. A Brief Guide To Understanding MOOCs. The Internet Journal of Medical Education. - 2011. - Vol. 1. - Number 2 [E-resource]. - Access mode: http://bit.ly/hZGiVG 
9. McAuley Alexander, Stewart Bonnie, Siemens George and Cormier Dave. The MOOC Model for Digital Practice / McAuley Alexander, Stewart Bonnie, Siemens George and Cormier Dave, - 2010. - 63 p.

10. OER Handbook for Educators 1.0 [E-resource]. - Access mode: http://wikieducator.org/OER_Handbook/educator_version_one

11. Prometheus - Ukrainian online educational platform http://terytoriya.com.ua/index.php/samovdoskonalennya/260-prometheus-ukrajinskaplatforma-onlajn-osviti

12. Results of the Course «History of Ukraine: from the Second World War to Modern Times» - http://prometheus.org.ua/history_info/\#.VNtvtXYFtIM.scoopit

13. Rosenberg M. The eLearning Guild's Handbook of e-Learning Strategy. The eLearning Guild. - 2007. P. 88

14. Siemens George. Connectivism: A Learning Theory for the Digital Age. December 12, 2004 [E-resource]. - Access mode: http://www.elearnspace.org/Articles/connectivism.htm

15. The MOOC Juggernaut: Year 2 - [E-resource]. - Access mode: http://www.blog.class-central.com/the-mooc-juggernaut-year-2

16. Ifenthaler, D. \& Gosper, M. (2014). Research-based learning: connecting research and instructions. Curriculum Models for the 21st Century: Using Learning technologies in Higher Education, 73-89. doi: 10.1007/978-1-4614-73-66-4_5.

\section{ПУТИ ИНТЕГРАЦИИ ЕВРОПЕЙСКИХ МАССОВЫХ ОТКРЫТЫХ ОНЛАЙН-КУРСОВ В УНИВЕРСИТЕТСКОЕ ОБРАЗОВАНИЕ УКРАИНЫ}

Бацуровская Илона Викторовна, кандидат педагогических наук, доцент кафедры электроэнергетики, электротехники и электромеханики, Николаевский национальный аграрный университет, bacurovska82@hotmail.com

Аннотация. Образовательные онлайн-курсы набирают все большую популярность. Образование является одной из немногих областей, где возраст и сохранение традиций являются преимуществами. В отличие от современного автономного образования это исследование вызвано личной мотивацией и желанием получить необходимые знания. В мировой практике концепция массовых открытых онлайн-курсов появилась давно. В статье представлен аналитический обзор способов внедрения европейских массовых открытых онлайн-курсов в университетское образование Украины и их возможности. Высшее образование нуждается в срочной реструктуризации. Массовые открытые онлайн-курсы могут помочь студентам повысить эффективность подготовки используя простоту и масштабность таких курсов.

Ключевые слова: Массовые открытые онлайн-курсы; образовательная сфера; платформы; университетское образование.

Ключевые термины: информация; информационно-коммуникационные технологии; технология. 


\section{СПОСОБИ ІНТЕГРАЦІЇ ЄВРОПЕЙСЬКОГО МАСОВОГО ВІДКРИТОГО ОНЛАЙН-КУРСУ В УНІВЕРСИТЕТСЬКУ ОСВІТУ В УКРАЇНІ}

Бацуровська Ілона Вікторівна, кандидат педагогічних наук, доцент кафедри електроенергетики, електротехніки та електромеханіки, Миколаївський національний аграрний університет, bacurovska82@hotmail.com

Анотація. Освітні онлайн-курси набирають все більшої популярності. Освіта $є$ однією з небагатьох областей, де вік і збереження традицій є перевагами. На відміну від сучасної автономної освіти це дослідження викликано особистою мотивацією i бажанням отримати необхідні знання. У світовій практиці концепція масових відкритих онлайн-курсів з'явилася давно. У статті представлено аналітичний огляд способів впровадження європейських масових відкритих онлайн-курсів в університетську освіту України та їх можливості. Вища освіта потребує термінової реструктуризації. Масові відкриті онлайн-курси можуть допомогти студентам підвищити ефективність підготовки використовуючи простоту і масштабність таких курсів. Метою даної статті $є$ аналітичний огляд шляхів впровадження європейських масових відкритих онлайнових курсів в університетську освіту України. Створені курси містять інтерв'ю 3 викладачами, провідні заняття, тематичні дискусійні форуми, тощо. Використання масових відкритих онлайн-курсів може забезпечити підготовку масштабнішої аудиторії, ніж традиційні заняття в кабінетах. Масові відкриті онлайн-курси дають змогу викладачам та студентам розвивати навички, знання та мислення, необхідні для участі у складних та змінних реальних ситуаціях. Відкритий процес навчання $\epsilon$ важливим аспектом відкритості в рамках всієї освітньої сфери. Це особливо корисно для професійного середовища фахівців, коли в курсах присутні відвідувачі з різними навичками та потребами.

Ключові слова: Масові відкриті онлайн-курси; освітня сфера; платформи; університетська освіта.

Ключові терміни: інформація; інформаційно-комунікаційні технології; технологія.

Стаття надійшла до редакиії 02.10.2017.

Прийнято до друку 23.11.2017. 